\title{
STUDENTS' PERCEPTIONS ABOUT THE EFFECTIVENESS OF MICRO TEACHING COURSES TOWARDS THE EDUCATIONAL COMPETENCE OF KPLP STUDENTS
}

\author{
Leni Apriani' ${ }^{1}$, Mimi Yulianti², Al Arismon ${ }^{3}$ \\ Universitas Islam Riau ${ }^{1,2,3}$ \\ leniapriani@edu.uir.ac.id¹,mimipenjas@uir.ac.id², alarismon@student.uir.ac.id
}

\begin{abstract}
The problems found by the researchers are as follows: 1) there are still deficiencies and ineffectiveness of micro teaching courses in providing teaching skills to students, 2) mental and grammatical readiness of Penjaskesrek children are still lacking to face KPLP, 3) pedagogic competencies possessed by students Jaskesrek Academic Year 2019/2020 is still not good. 4) there are still many students who have difficulty in preparing teaching materials and the difficulty of using media in learning at school, and 5) the seriousness of students in the teaching and learning process is still low because those who teach in the class are KPLP students. Teaching on the Pedagogic Competence of KPLP Students. The method used is descriptive quantitative research. The population in this study were all sixth semester students for the 2020/2021 academic year. This research was conducted at the Islamic University of Riau. With total saturated sampling technique. The total sample is saturated with the sampling technique when all members of the population are used as samples, while the research sample is 156 students. Students' perceptions of course activities in the KPLP are stated in the Enough category. This is evidenced by the average acquisition of the questionnaire, namely student perceptions of course activities in the KPLP stated in the Enough category. This is evidenced by the average acquisition of the questionnaire, which is $64.10 \%$ which is in the range of $60 \%$ $74 \%$ in the Enough category. Student perceptions of pedagogic competence in KPLP are stated in the Enough category. This is evidenced by the average acquisition of the questionnaire, which is $69.88 \%$ which is in the range of $60 \%-74 \%$ in the Enough category. This situation is due to the COVID-19 virus outbreak which has made KPLP activities in FKIP ineffective, especially the PENJASKESREK Study Program.
\end{abstract}

Keywords: Perception, Pedagogy, Microteaching

Accepted: $08^{\text {th }}$ of January 2022

Correspondence author: Leni Apriani, Universitas Islam Riau. E-Mail: leniapriani@edu.uir.ac.id

DOI http://dx.doi.org/10.31851/hon.v5i1.6723 do

(c) (i) (2)

Jurnal Halaman Olahraga Nusantara licensed under a Creative Commons Attribution-ShareAlike 4.0 International License

\section{INTRODUCTION}

The world of education is very important for every human being. Humans as individuals who really need education so that individuals are able to keep up with the times that are increasingly sophisticated and modern. Education carried 
out by the government seeks to advance and improve Human Resources (HR) in order to improve lives more.

Education is one element that is very influential on the progress of a country. It is hoped that with this education human resources can learn from various things ranging from skills, attitudes to other knowledge. The success of an education can be determined by several important components. When viewed as a whole, currently teachers in Indonesia are really concerned (Fitria et al., 2018).

Teachers as professionals are tasked with planning and implementing learning, assessing learning outcomes, conducting guidance and training, conducting research, assisting in the development and management of school programs and developing their professionalism. Learning is a two-way communication process, teaching is done by educators, and learning is done by students (Azizah \& Rahmi, 2019).

Shows that the profession of a teacher has complexity, especially in terms of shaping human learning in the context of national education. With its various functions, it can be concluded that the teacher has a dominant role and acts as the spearhead of the nation's education. The implication is that the quality of the nation's education is influenced by the quality of its educators (Febrian \& Fera, 2019).

One of the competencies that is a concern in the learning process is pedagogic competence, which is the ability of teachers to understand students, planning and implementing learning, evaluating learning outcomes, and developing students' potential. Teachers have the main task of educating, teaching, guiding, directing, training, assessing and evaluating students, in carrying out these main tasks the teacher must have competencies such as pedagogic competence, professional competence, social competence, personality competence (Untari et al., 2018).

Pedagogic competence as the main competence that must be possessed by the teacher so that the learning carried out will be more effective and efficient. 


\section{OLAHRAGA}

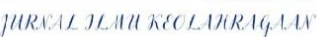

Jendral A. Yani Street Lorong Gotong Royong 9/10 U1 Palembang South Sumatera

email jurnal: jurnalhon@univpgri-palembang.ac.id situs web: http://www.univpgri-palembang.ac.id
Accredited

SINTA 3

The learning process carried out by the teacher does not only explain from teacher to student, but also requires competence to manage learning so that students can accept learning easily. Here the teacher must also be professional in shaping the social personality. Pedagogic competence is the ability to manage learning which includes understanding of students, planning, implementation, and evaluation of student development learning (Rahayu \& Mertha, I, 2017).

The delivery of learning materials in order to be efficient and effective requires a learning method. The ways that teachers do in carrying out learning tasks often change terms ranging from teaching strategies, teaching styles to learning methods. However, in principle, the use of the three terms has the same meaning, namely the teacher's strategy to encourage student participation to carry out teaching tasks (Agus, Rachmi, 2019).

Micro teaching, prospective educators have the opportunity to improve effective behavior in the learning environment. In other words, the existence of micro teaching provides an opportunity for the discovery of more effective methods. After teaching, the practitioner's recordings are analyzed or researched to find out their shortcomings so that they inspire observations to provide input. Providing input is very useful for more effective teaching.

Micro teaching is an early stage of training in the formation of teaching competencies through the actualization of basic teaching. Basically, micro teaching is a performance-based learning method whose technique is carried out by training the components of basic teaching competencies (teaching skills) in the learning process so that prospective teachers are truly able to master each component one by one or several components in an integrated manner in a learning situation. which is simplified or minimized seen from the aspect of learning components, student material, and time. Student perception is an important part because it relates to the assessment of microteaching courses (Rahmawati \& Suriani, 2016). This assessment is a form of response from 


\section{Accredited}

SINTA 3

students' perceptions after taking microteaching courses in carrying out the learning process.

Based on the observations of researchers while teaching micro learning courses or micro teaching, many problems were found, including: 1) there are still shortcomings and ineffectiveness ofcourses micro teaching in providing teaching skills to students, 2) mental readiness and grammar of Penjaskesrek children are still lacking. to deal with KPLP, 3) The pedagogic competence of Penjaskesrek students for the Academic Year 2019/2020 is still not good. 4) there are still many students who have difficulty preparing teaching materials and the difficulty of using media in learning at school, and 5) the seriousness of students in the teaching and learning process is still low because those who teach in class are KPLP students. Restrictions forcing educational activities educational actors (teachers and students) to learn and learning from home in virtual (online) (Rahman, Taufik. Prasetyo, Dyas, Andry. Mashuri, 2021).

\section{METHOD}

Type of research is quantitative descriptive research. According to quantitative data, it is data in the form of numbers, or qualitative data that is scored (scoring). This research was conducted at the Islamic University of Riau, Penjaskesrek Study Program. The population in this study was 156 students. The sampling technique in this research is saturated sampling. Saturated sampling is a sampling technique when all members of the population are used as samples (Sugiyono, 2018). So the sample of this research is all semester VI T.A 2019/2020 PENJASKESREK students as many as 156 students.

The data analysis technique used in this study was to describe the results of the students' perception questionnaire scores about the effectiveness of thecourse micro teaching on the pedagogic competence of the students of the Educational Field Practice Lecture (KPLP). To obtain the data in this study, the development of the instrument used was a Likert Scale. The Likert scale is used to measure attitudes, opinions, and perceptions of a person or group of people about 
social phenomena (Sugiyono, 2017).

Following is a design of the research instrument grid on the student perception questionnaire about the effectiveness of thecourse micro teaching on the pedagogic competence of the students of the Educational Field Practice Lecture (KPLP):

Table 1. Alternative Answers According to the Likert Scale

\begin{tabular}{lcc}
\hline \multirow{2}{*}{ Alternative answers } & \multicolumn{2}{c}{ Score Statement } \\
\cline { 2 - 3 } & Positiv & Negativ \\
\hline Strongly Agree & 4 & 1 \\
Agree & 3 & 2 \\
Disagree & 2 & 3 \\
Strongly Disagree & 1 & 4 \\
\hline
\end{tabular}

Table 2. Grid of Student Perception Questionnaire on the Effectiveness of Courses Micro Teaching

\begin{tabular}{cl}
\hline Variable & Indicator \\
\hline & Infrastructures Micro Teaching \\
& Process of Micro Teaching \\
Class Effectiveness Micro & Benefits Implementation of Micro Teaching \\
Teaching in equipping KPLP & Contributions Lecturer in Learning Micro Teaching \\
& Evaluation inLearning Process Micro Teaching
\end{tabular}

Table 3. Grid of Student Perception Questionnaire About Pedagogic Competence of KPLP Students

\begin{tabular}{ll}
\hline Variable & \multicolumn{1}{c}{ Indicator } \\
\hline & $\begin{array}{l}\text { Students Student Characteristics } \\
\text { MasteringMastering Learning Theory Concepts and } \\
\text { Learning Principles }\end{array}$ \\
& Development of the Latest Curriculum \\
KPLP Student Pedagogic & Activities in the Learning Process That Educate \\
Competence & $\begin{array}{l}\text { Students' Potential Development } \\
\text { Communication between Teachers and Students }\end{array}$ \\
& $\begin{array}{l}\text { Assessment and Evaluation Conducted by Teachers } \\
\text { to Students }\end{array}$ \\
\hline
\end{tabular}


After the data is collected through a questionnaire, then data analysis is carried out, namely each response response is calculated as a percentage. Calculation of the percentage of response results using the formul (Sudjana, 2014) as follows:

$$
P=\frac{f}{N} \times 100 \%
$$

Description :

$\mathrm{P}=$ Percentage number

$\mathrm{F}=$ Frequency

$\mathrm{N}=$ Total number of respondents

Table 4. Rating Norms

\begin{tabular}{lll}
\hline Percentage Interval & Scale Value & Description \\
\hline $85 \%-100 \%$ & A & Very Good \\
$75 \%-84 \%$ & B & Good \\
$60 \%-74 \%$ & C & Fair \\
$40 \%-59 \%$ & D & Less \\
$0 \%-39 \%$ & E & Fail \\
\hline
\end{tabular}

(Sunarti, 2014)

\section{RESULT AND DISCUSSION}

In accordance with the problems contained in the previous section that have been described, this chapter will provide an explanation of the results of data research. The data were obtained from distributing questionnaires to the sample, namely students who had completed their final lectures in the semester VI of the 2019/2020 Academic Year in the PENJASKESREK department at the Faculty of Teacher Training and Education, Riau Islamic University, totaling 156 people. Analysis of the questionnaire was carried out based on the indicators that had been made and classically from the overall indicators of student perceptions about the effectiveness of courses micro teaching. The complete description of the questionnaire data analysis of student perceptions and pedagogic competencies in semester VI is as follows: 


\section{OLAHRAGA

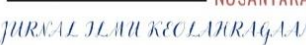 \\ Jendral A. Yani Street Lorong Gotong Royong 9/10 U1 \\ Palembang South Sumatera \\ Accredited \\ email jurnal: jurnalhon@univpgri-palembang.ac.id \\ situs web: http://www.univpgri-palembang.ac.id

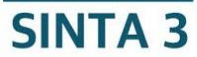

1. Analysis of Student Perceptions on the Effectiveness ofcourses for micro teaching the semester VI of KPLP PENJASKESREK students for the 2019/2020 academic year.

Based on the results of the distribution of the questionnaire to the sample, the results obtained from the analysis of student perceptions about the effectiveness of the course in micro teaching semester VI. PENJASKESREK students for the academic year 2019/2020 obtained 53 or 33.98\% category strongly agree, 100 or $64.10 \%$ agree category 3 or $1,92 \%$ disagree category and 0 or $0 \%$ strongly disagree category. The results of the data recapitulation are presented in histogram 1.

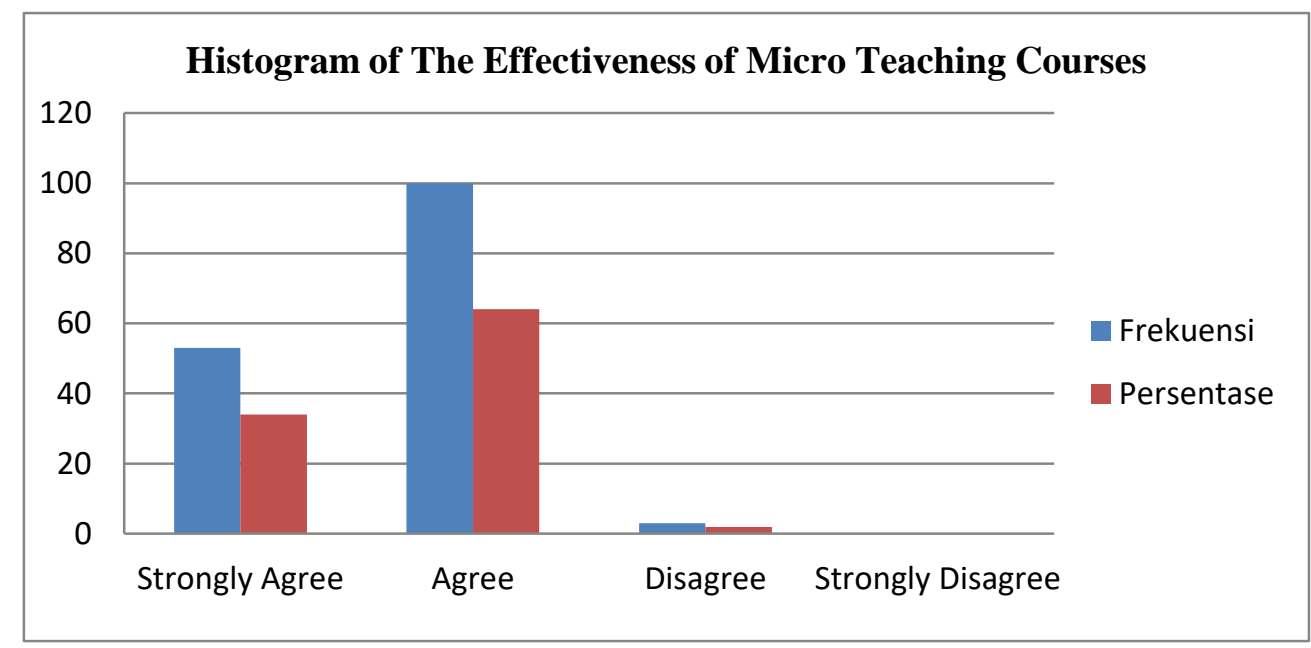

2. Analysis of Student Perceptions about Pedagogic Competence forcourses for micro teaching the semester VI of KPLP PENJASKESREK students for the 2019/2020 academic year.

Based on the results of the distribution of the questionnaire to the sample, the results of the Student Perception Analysis on pedagogic competence in semester VI of PENJASKESREK students for the 2019/2020 academic year were obtained 47 or $30.12 \%$ in the category strongly agree, 109 or $69.88 \%$ in the category agree, 0 or $0 \%$, in the disagree category. agree and 0 or $0 \%$ strongly disagree. The results of the data recapitulation are presented in histogram 2. 


\section{HALAMAN Jendral A. Yani Street Lorong Gotong Royong 9/10 Ulu OLAHRAGA Palembang South Sumatera

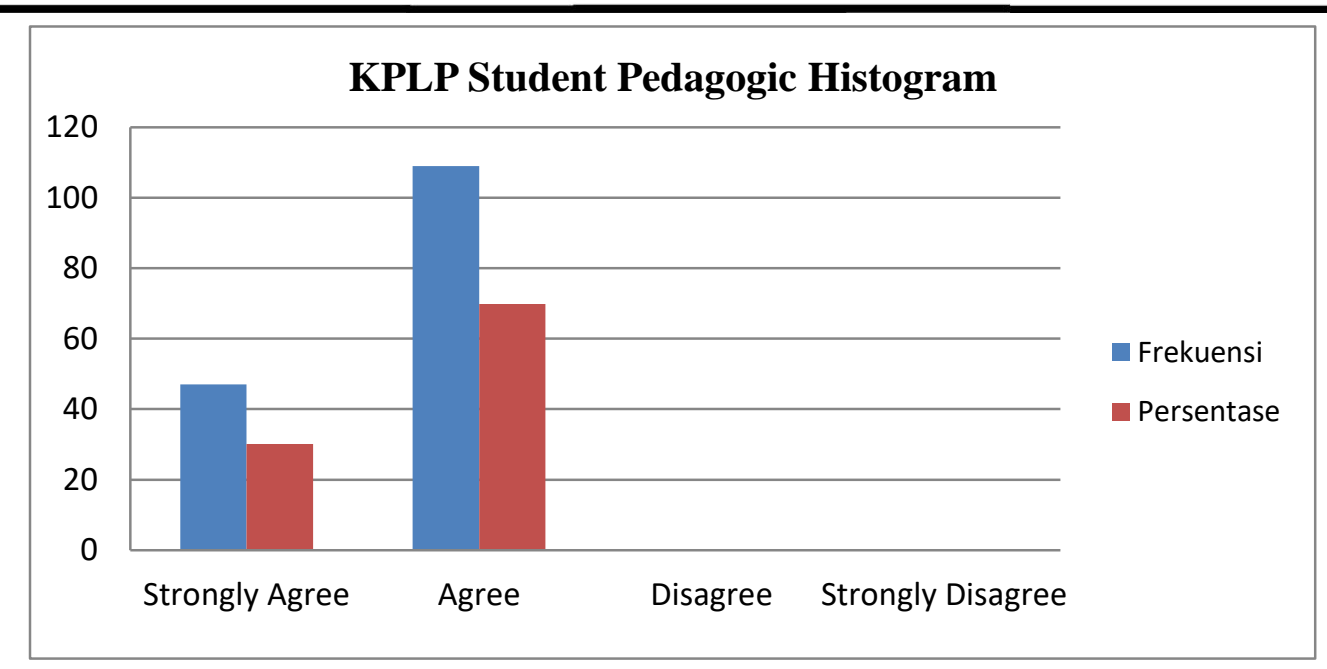

Giving an explanation is a very important aspect in teaching activities because in learning the interactions between teachers and students interact with each other both in the classroom and outside the classroom (Lubis et al., 2019). he micro learning course contains the nature of micro learning and eight basic teaching skills. In addition to the preparation of students themselves which can determine the formation of basic teaching skills, lecturers and tutor teachers also have a role in their formation through the process of mentoring, guiding, directing prospective teacher students during PPL at school (Meha \& Bullu, 2021)

It can be seen from previous research, Overall it is in the medium category, which is $35 \%$. While the remaining $15 \%$ is in the very low category, $15 \%$ is in the low category, $25 \%$ is in the high category, $10 \%$ is in the very high category (Hartono, 2019).

Based on the results obtained, it shows that the implementation of Student Perceptions about the Effectiveness of Micro teaching Courses on the Pedagogic Competence of KPLP Students in the PENJASKESREK Department for the Academic Year 2019/2020 is in the sufficient category. This situation is due to the COVID-19 virus outbreak which has made KPLP activities in FKIP ineffective, especially the PENJASKESREK Study Program. Usually KPLP is carried out in schools in the RIAU area, in 2020 KPLP is carried out by lecturers at FKIP and does not hold face-to-face meetings. 
This is reinforced by previous research which concluded as follows: 1) The constraints on microteaching lectures in preparing students to carry out the Field Experience Program (PPL) were only the availability of facilities which included study rooms $(58.1 \%)$ and LCD $(51.8 \%)$. 2) Student perceptions of the effectiveness of microteaching courses on the implementation of the Field Experience Program (PPL) for undergraduate students of the Biology Education Study Program, FMIPA State University of Medan FY 2015/2016, that Microteaching courses are effective for the successful implementation of the Field Experience Program (PPL) from the aspect of lecturers subjects $(75.1 \%)$ and students $(80.8 \%)$ while the facilities aspect is quite effective (55\%) (Rahmawati \& Suriani, 2016).

\section{DISCUSSION}

After the research data is described per indicator aspect, the next step is to find the overall average score in order to determine the level of effectiveness of the Micro teaching Course on the Pedagogic Competence of KPLP Students in the PENJASKESREK Department for the Academic Year 2019/2020. Later the score is compared with the percentage criteria that have been described. For more details, the average score for each aspect of the Micro teaching Course Effectiveness variable on the Pedagogic Competence of KPLP Students in the PENJASKESREK Department for the Academic Year 2019/2020.

Table 5 . Recapitulation of Average Answer Scores of Respondents Perceptions of Students About the Effectiveness of Courses on Micro teaching Pedagogic Competencies of KPLP Students in the Department of Physical Education, Academic Year 2019/2020

\begin{tabular}{llll}
\hline No & \multicolumn{1}{c}{ Indicator } & Average & Category \\
\hline 1 & Student Perceptions about the & $64,10 \%$ & Enough \\
& $\begin{array}{l}\text { Effectiveness of Micro teaching courses } \\
2\end{array}$ & $\begin{array}{l}\text { Student Perceptions about Pedagogic } \\
\text { Competence }\end{array}$ & $69,88 \%$ \\
\end{tabular}


After the calculation is done, the category of each indicator is obtained. Based on students' perceptions of the effectiveness of micro teaching courses, the average assessment criteria is $64.10 \%$ and students' perceptions of pedagogic competence are $69.88 \%$ in the range of $60 \%-74 \%$ in the Enough category. Therefore, based on the criteria for Student Perceptions About the Effectiveness of Micro teaching Courses on the Pedagogic Competence of KPLP Students, PENJASKESREK Department, Academic Year 2019/2020.

Being a professional teacher candidate, education students should have pedagogic competence. Pedagogic competence is the ability to manage learning which includes understanding of students. The aspect of delivering material is one form of mastery of pedagogic competence (Syukriadi \& Rozi, 2021). Pedagogy itself is a competency that shows the teacher's ability to manage learning, including the implementation of learning (Okilanda et al., 2021).

Micro-teaching is a form of educational practice model or teaching training for prospective teachers on campus. In accordance with the actual context, teaching contains many actions, including technical delivery of material, use of learning methods, use of learning media, guiding learning, motivating, managing classes, providing assessments and so on (Ardi, 2014).

Regarding student perceptions of the role of micro teaching and teaching readiness, it can be concluded that student perceptions of the role of micro teaching courses have a significant and positive effect on teaching readiness(Azizah \& Rahmi, 2019).

\section{CONCLUSION}

Based on the results of research and data analysis conducted, it can be concluded that:

1. Students' perceptions of course activities in the KPLP are stated in the Enough category. This is evidenced by the average acquisition of the questionnaire, which is $64.10 \%$ which is in the range of $60 \%-74 \%$ in the Enough category. 
2. Students' perceptions of pedagogic competence in KPLP are stated in the Enough category. This is evidenced by the average acquisition of the questionnaire, which is $69.88 \%$ which is in the range of $60 \%-74 \%$ in the Enough category.

\section{REFERENCES}

Agus, Rachmi, M. (2019). Pengaruh Metode Pembelajaran Dan Kriteria Layanan Bantuan: Meningkatkan Gerak Dasar Lompat Jauh Gaya Jongkok Siswa Tunagrahita Ringan Pada Pembelajaran Penjasorkes Slb Pkk Bandar Lampung. Halaman, 2(2), 186-197. https://doi.org/10.31851

Ardi, M. (2014). Pelaksanaan pembelajaran bagi mahasiswa program studi PPKn STKIP-PGRI Pontianak. Jurnal Edukasi, 1(1), 75-84.

Azizah, N., \& Rahmi, E. (2019). Persepsi Mahasiswa Tentang Peranan Mata

Kuliah Micro Teaching Terhadap Kesiapan Mengajar Pada Mahasiswa

Pendidikan Ekonomi UNP. EcoGen, 2(2), 197-205. https://doi.org/10.24036/jmpe.v2i2.7312

Febrian, \& Fera, M. (2019). Kualitas Perangkat dan Keterampilan Mengajar Mahasiswa Pendidikan Matematika pada Mata Kuliah Micro Teaching Menggunakan Analisis Model Rasch. Jurnal Gantang, 4(1), 87-95. https://doi.org/10.31629/jg.v4i1.1065

Fitria, I., Syamwil, S., \& Syofyan, R. (2018). Persepsi Mahasiswa Tentang Efektivitas Program Pengalaman Lapangan Kependidikan (PPLK) Terhadap Kesiapan Menjadi Guru Pada Mahasiswa Pendidikan Ekonomi Unp. Jurnal Ecogen, 1(2), 422. https://doi.org/10.24036/jmpe.v1i2.4764

Hartono, R. (2019). Persepsi Guru Penjas Terhadap Kompetensi Mahasiswa Magang 2 Prodi Penjas FKIP UNIB dI SMP Negeri Kota Bengkulu Tahun 2018. KINESTETIK: Jurnal Ilmiah Pendidikan Jasmani, 3(2), 165-173. https://doi.org/10.33369/jk.v3i2.8911

Lubis, A., Hanafi, \& Siregar, Rabiyatul, A. (2019). Efektivitas Sistem Pengelolaan Microteaching Dengan Siklus Penetapan, Pelaksanaan, Evaluasi, Pengendalian Dan Peningkatan (PPEPP) Dalam Meningkatkan Keterampilan Mengajar Calon Guru Institut Pendidikan Tapanuli Selatan. 7(4), 168-174. https://doi.org/10.37081/ed.v7i4.1403

Meha, A. M., \& Bullu, N. I. (2021). Hubungan Kesiapan Mengajar Dan Proses Praktik Pengalaman Lapangan Dengan Keterampilan Dasar Mengajar Mahasiswa Pendidikan Biologi. Edukatif: Jurnal Ilmu Pendidikan, 3(2), 412-420. https://doi.org/10.31004/edukatif.v3i2.323 
Okilanda, A., Dlis, F., Humaid, H., Putra, D. D., Arisman, A., \& Muslimin, M. (2021). Defense Warm-Up Exercise Material for 13-Age Athlete Using Video Technology in Covid-19 Era. International Journal of Human Movement and Sports Sciences, 9(4), 629-634. https://doi.org/10.13189/saj.2021.090404

Rahayu, S., \& Mertha, I, G. (2017). Pengembangan Bahan Ajar Micro Teaching Untuk Melatih Kompetensi Pedagogik Calon Guru. Jurnal Pendidikan Fisika Dan Teknologi, 3(2), 232-238.

Rahman, Taufik. Prasetyo, Dyas, Andry. Mashuri, H. (2021). The Impact Of Online Learning During The Covid-19 Pandemic On Physical Education Teachers. Halaman Olahraga Nusantara (HON), 4(II), 294-304. https://doi.org/10.31851

Rahmawati, L., \& Suriani, C. (2016). Persepsi Mahasiswa Tentang Efektivitas Mata Kuliah Microteaching Terhadap Pelaksanaan Program Pengalaman Lapangan (PPL) Mahasiswa S1 Program Studi Pendidikan Biologi FMIPA Universitas Negeri Medan. JURNAL PELITA PENDIDIKAN, 4(3), 58-63.

Sudjana, N. (2014). Penilaian Hasil Proses Belajar Mengajar. PT Remaja Rosdakarya.

Sugiyono. (2017). Metode Penelitian Kuantitatif Kualitatif dan R\&D. Alfabeta.

Sugiyono. (2018). Metode Penelitian Pendidikan Pendekatan Kuantitatif, Kualitatif, dan $R \& D$. Alfabeta.

Sunarti. (2014). Penilaian Dalam Kurikulum 2013. C.V ANDI OFFSET.

Syukriadi, A., \& Rozi, F. (2021). Perspektif Mahasiswa Terhadap Perkuliahan Pendidikan Jasmani di IAIN Salatiga. Jurnal Universitas Islam Kalimantan, 4(1), 40-45.

Untari, T., Rahmaniah, R., Islami, A. B., Ihsani, B. Y., \& Artikel, S. (2018). Peningkatan Pembelajaran Microteaching Melalui Pendekatan Kolaboratif. Jurnal Prakarsa Paedagogia, 1(1), 91-100. https://doi.org/10.24176/jpp.v1i1.2616 